\title{
CORPORATE DERIVATIVES AND RISK MANAGEMENT: A MODERATED MEDIATION TEST
}

\author{
Atia Alam \\ Assistant Professor, Kinnaird College for Women, Lahore \\ atia.alam@kinnaird.edu.pk \\ Talat Afza \\ Professor, University of Lahore, Lahore \\ afza.talat@gmail.com
}

\begin{abstract}
The present study contributes to existing literature by empirically testing the moderated mediating role of firm's risk on the relationship between derivative usage and firm value by gathering sample data of Pakistani and Malaysian non-financial firms. By using Bootstrap technique of Hayes (2015), study finds that the use of derivative has both direct and indirect effect on firm value in Pakistan, contrary to Malaysia, as derivative usage significantly enhances firm value by reducing firm's risk. Findings remain same for both foreign currency and interest rate derivative usage that firm's risk significantly mediates the relationship between derivative usage and firm value in Pakistani nonfinancial corporations.
\end{abstract}

Keywords: Derivative Usage, Firm Value, Firm's Risk, Moderated Mediation, Pakistan and Malaysia.

JEL Classification Codes: G1, G32, F310,

\section{INTRODUCTION}

Derivatives are widely used by corporations as a risk management instrument to hedge exchange rate and interest rate volatility since the last two decades, especially Asian financial crises gave a strong reminder to corporations to use derivatives as risk management instrument. Financial theorists argued that risk management by derivatives may add firm value under certain market imperfections, i.e., financial distress costs (Mayers \& Smith, 1982; Smith \& Stulz, 1985; Leland, 1998); underinvestment problem (Myers \& Majluf, 1984; Froot et al., 1993), managerial risk aversion (Smith \& Stulz, 1985; Demarzo \& Duffie, 1995) and agency costs (Tufano, 1996). Hedging theorists' state that deadweight costs associated with these market imperfections reduce firm's operating cash flow variability, which in turn enhances firm value.

Many studies have examined the direct relationship of derivative usage and firm value and found mixed evidence in support of both value increasing (Allayannis \& Weston, 2001; Graham \& Rogers, 2002; Clark \& Mafteh, 2010) and decreasing effects of derivative usage on firm value (Fauver \& Naranjo, 2010; Nguyen \& Faff, 2010). Few researchers have also examined the effect of derivative usage coupled with firm's risk on value and find mixed results regarding value increasing effects of derivative usage (Naranjo \& Fauver, 2010; Chen et al., 2014). Despite growing significance of derivative usage over the past few decades, empirical evidence regarding 'how' and 'when' usage of derivative instruments enhances firm value is still not clear. The current study therefore primarily contributes to the existing literature by empirically examining ' $h o w$ ' and 'when' derivative usage increases firm value by using moderated mediation technique of Hayes (2015). Financial theorists argued that derivative usage increases firm value by reducing risk, therefore, mediating role of firm' risk has been tested on the relationship between derivative usage and firm value. In addition to this, researchers also stated that usage of derivative in presence of firm's risk enhances firm value. The present study, therefore, hypothesizes that derivative usage moderately mediates the indirect relationship of derivative usage and firm value. Moreover, the current literature based on in-depth analysis is mostly centred on countries where derivative markets are developed.

The present study adds to the existing literature by conducting an in-depth analysis based on firm's ER and IR exposure in countries where derivative markets are under-developed. The study 
therefore comparatively analyzes the risk management role of derivative usage by using sample data of 166 and 266 Pakistani and Malaysian non-financial firms. Selection of sample data is backed by a couple of reasons. At first, both the countries got independence under the same British rule and faced almost similar economic and cultural values. At second, both the countries have underdeveloped derivative and capital markets and mostly used over the counter derivative instruments for risk management purpose. At last, despite earlier independence of Pakistan from British Rule, Malaysia has comparatively more developed financial markets and therefore expects to use derivative instruments more for risk management. Present study, hence, aims to empirically test how financial derivatives enhance firm value by reducing firm risk of non-financial firms of Pakistan and Malaysia. In addition to this, study examines is risk management role of financial derivatives vary across nonfinancial firms of Pakistan and Malaysia.

The present study will help decision-makers in identifying whether the risk management role of derivative usage significantly differs between countries or not? Moreover, existing literature mostly focusses on countries where derivative markets are developed while current study will facilitate managers and investors in identifying the risk management role of derivatives in countries where derivative markets are in development stage.

Remaining study is structured as follows: section two reviews the relevant existing literature addressing the risk management usage of derivative instruments and its value relevance. Sample data and methodology is described in section three, while empirical findings and discussions are reported in section four. Section five concludes the study followed by policy implications and future directions.

\section{REVIEW OF LITERATURE}

Concerning the growing usage of derivative instruments, a large number of studies examined a direct relationship between derivative usage and firm value, though studies are mostly based on developed countries having amateur derivative market. Like, Kapitsinas (2008) examined 81 Greece firms and documented that use of derivative instruments, both FCD and IRD, increased firm value. Similar findings were observed by Junior and Laham (2008), Leon et al., (2009), Clark and Maftah (2010), and Chang et al., (2010). Allayannis et al., (2012) examined foreign firms across 39 countries for the period of 1990-1999 and depicted that usage of derivatives gave value premium to firms, especially corporations having ER exposure. By empirically examining Pharmaceutical and biotech U.S. companies for the period of 2001-2006, Choi et al., (2013) found significant positive effects of financial hedging on the firm value, whereas operational hedging enhanced firm value when used in conjunction with financial hedging.

Panaretou (2014) studied 350 UK firms for the period of 2003-2010 and found that almost $86.88 \%$ firms used derivatives. Study depicted the significant positive relationship of FCD usage with firm value, while the relationship weakened while tested the influence of IRD usage on firm value. Paligorova and Staskow (2014) examined Canadian non-financial firms for the period of 2006-2013 and suggested that hedging through derivatives may increase firm value as hedger's possessed higher profits and lower earnings volatility. Vivel Bua et al., (2015) examined the value creation from financial derivatives in Spanish firms and illustrated that financial derivatives had an increasing value effect on firm value. While this positive effect varied with the volume of hedging through derivatives. Krause and Tse (2016) argued that risk management through derivatives increased firm value and performance while minimized financial distress costs.

Lau and Kwong (2016) observed that despite of negative valuation of derivative usage by capital market participants, derivative employment for risk management instrument enhanced firm's accounting profits. Study furthermore depicted that firm's having thing operating margin has more opted to use derivatives for managing their financial risk. Leene and Oki (2017) examined the effect of both interest rate and foreign currency derivative usage on firm value separately. Results showed that interest rate derivatives had significant positive effect on firm value whereas, foreign exchange derivative failed to enhance value of UK firms. Luo and Wang (2018) demonstrated significant positive effect of derivative usage on firm value, and this effect increased during exchange rate depreciation period. While the relationship between derivative usage and firm value turned to be weaker during crises period.

Frensidy and Mardhaniaty (2019) observed significant positive role of foreign currency derivative usage on value of Indonesian firms. While no effect had seemed regarding interest 
derivative usage and firm value. Zamzamir et al., (2021) showed a non-linear relationship between foreign currency derivative usage and firm value. Study furthermore stated that selective hedging approach is more value increasing rather that aggressive usage of financial derivatives for hedging purpose. By employing Meta-analysis approach, Bachiller et al., (2021) stated that financial derivatives, of all types, determined firm value positively and this effect was stronger in developed countries.

Few studies have found the speculative use of derivative instruments as employment of derivative instruments decreased firm value for instance; Fauver and Naranjo (2010) by using 1,746 U.S. non-financial for the period of 1991-2000, showed that derivative usage had a significant negative effect on firm value. Robustness results also illustrated that derivative usage, coupled with firm's agency and monitoring problems, decreased firm value. Khediri and Folus (2010) gathered data of 320 non-financial French firms for the year 2001 and found a significant negative relationship between derivative usages with firm value. Analyzing 469 Australian firms, Nguyen and Faff (2010) demonstrated that derivative usage leads to value discount in general and especially for swap contract due to higher default risk associated with them. Phan et al., (2014) examined 94 U.S. Oil and gas exploration companies for the period of 1998-2009 and found and negative effect of derivative usage on firm value when oil and gas prices were high and vice versa. In addition to this, the study demonstrated that hedgers underperformed non-hedgers in case of a rise in oil and gas prices. Bae et al. (2019) tested the relationship between foreign currency derivative usage and value of Korean firms. Results illustrated discount effect of derivative usage on firm value despite of risk exposure faced by them.

Few researchers have empirically found that usage of the derivative is irrelevant of firm value like; Naito and Laux (2011), by considering 434 S\&P non-financial firms for the year 2011, reported the insignificant impact of derivative usage on firm value. By testing sample data of Turkish nonfinancial firms, Ayturk et al., (2016) depicted insignificant effect of financial derivatives on firm value. Results, however, showed significant positive effect only when system GMM dynamic model had used for regression analysis. Similarly, Akpinar and Fettahoglu (2016) also found insignificant positive relationship between derivative usage and value of Turkish non-financial firms. Firmmansayah and Purnama (2020) argued that Indonesian investors' might not understand the role of derivatives in managing firm risk and hence usage of financial derivatives in Indonesian market was irrelevant of firm value.

After Asian financial crises 97/98, researchers start addressing whether corporations are using derivative instruments for risk management purpose or not, in order to minimize the adverse effects of highly volatile ER and IR movements. For instance, Allayannis et al., (2001a) analyzed 327 firms from the eight East Asian countries for the period of 1997-1999 and depicted the significant negative effect of hedging on firm's equity returns during the crisis period, while in post-crisis period hedging enhanced firm's equity returns. Ameer (2009) investigated the value relevance of FCD and IRD usage for the period of 2003-2007 by using-data of 40 non-financial Malaysian firms and found significant positive effects of derivative usage, both FCD and IRD, on firm value. Bashir et al., (2013) studied 105 Pakistani non-financial firms for the period of 2006-2010 and depicted no significant relationship between corporate derivatives and firm value. However, the relationship turned to be significantly negative and positive effect of FCD and IRD usage on firm value respectively. Afza and Alam (2016) illustrated significant positive role of foreign currency derivatives in enhancing value of Pakistani non-financial firms.

Concluding the above literature, studies have mostly tested the value premium effect of derivative usage, but to the best of the author's knowledge, till now no study has empirically examined how derivative usage increases firm value through firm's risk. The present paper attempts to fill this gap by bringing new evidence in the empirical literature by analyzing a mediating effect of a firm's risk on the relationship of derivative usage with firm value. As, risk management theorists state that derivatives increase firm value by reducing firm's risk (Froot et al., 1993; Tufano, 1998; Monda et al., 2013; Bartram et al., 2011; Phan et al., 2014). Literature, however, has shown a significant association between derivative usage and firm value, but empirical analysis of 'how' this relationship occurs is still unavailable. In addition to this, few studies have empirically examined the influence of derivative usage along with firm's risk on value (Naranjo \& Fauver, 2010; Chen \& King, 2014; Phan et al., 2014). They hypothesized that in presence of firm's risk, usage of derivatives, 
enhances firm value, though findings are contradictory in nature, supporting both speculative and risk management usage of derivative instruments. But for the best of author's knowledge, no study has tested the moderated role of derivative usage on firm's risk and value. Study, hence, tries to fill this gap by primarily contributing to current literature by examining the moderated mediating effect of firm's risk on the relationship between the corporate derivative and firm value in order to empirically analyze 'how' and 'when' usage of derivative instruments increases firm value. The study hypothesizes that usage of derivative instruments indirectly enhances firm value through a reduction in firm's risk, while the indirect path influenced directly by moderating role of derivative usage itself by using a Bootstrap method by Hayes (2015).

\section{$H_{1}$ : Firm risk moderately mediates a relationship between derivative usage and firm value.}

The present study, therefore, facilitates decision makers and policy makers in identifying the role of derivative used as a risk management instrument by understanding how derivative usage, directly and indirectly, enhances firm value.

\section{METHODOLOGY}

The study gathers sample data of 166 Pakistani and 266 Malaysian firms listed on Karachi Stock Exchange and Bursa Stock exchange respectively for the period of 2004-2010 and represents almost $35 \%$ of total population. Firms that are either merged or demerged and listed or de-listed are not included in the sample data. Moreover, financial firms are excluded from the sample data as they are both trader and user of derivative instruments, therefore inclusion of financial firm's makes empirical results unbiased. Firms are classified as users and non-users based on their disclosure regarding information about derivative usage in their respective non-financial firms.

As described previously, the study examines the role of derivatives as a risk management instrument through moderated mediation analysis by using the PROCESS tool of the bootstrap technique by Hayes (2012). As financial theorists state that risk management increases firm's value by reducing firm's risk (Merton, 1989; Bartram et al., 2011). The present study therefore empirically examines whether firm's risk works as a mediating variable while testing the influence of corporate derivative usage on the firm value or not? Moreover, the study analyzes the influence of derivative usage coupled with firm's risk on value and explores whether derivative usage in the presence of firm's risk increases firm value or not. The current study, therefore, tests whether the influence of firm's risk on value is positively moderated by derivative usage or not? Hence, the indirect path by which derivative usage effects firm value is contingent on derivative usage itself, similar models were presented by Judd and Kenny (1981) and James and Brett (1984) where the independent variable is also a moderator of the indirect path. The study, hypothesizes that mediating effect of firm's risk on the relationship of derivative usage and firm value is dependent on the level of the derivative usage itself as shown in the Statistical model in figure 1:

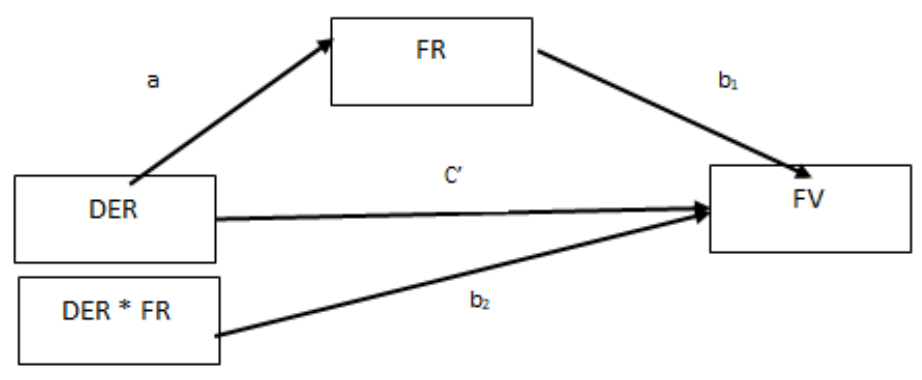

Figure 1: Statistical Model of Moderated Mediation

Hayes (2015) however defined moderated mediation as "A mediation process is said to be moderated if the proposed moderator variable has a non-zero weight in the function linking the indirect effect of $\mathrm{X}$ on $\mathrm{Y}$ through $\mathrm{M}$ to the moderator." They identified non-zero weight as a product of the two regression coefficients and identified as the index of moderated mediation. A significant non-zero value index illustrates the presence of moderated mediation. Models are described as: 


$$
\begin{aligned}
& \mathrm{FR}=\alpha+\mathrm{a} \mathrm{DER}_{\mathrm{it}}+\varepsilon_{\mathrm{it}} \ldots \ldots \ldots \ldots \ldots \ldots . . . \\
& \mathrm{FV}=\alpha+\mathrm{b}_{1} \mathrm{FR}_{\mathrm{it}}+\mathrm{c}^{`} \mathrm{DER}_{\mathrm{it}}+\mathrm{b}_{2}\left(\mathrm{FR} * \mathrm{DER}_{\mathrm{it}}\right)+\varepsilon_{\mathrm{t} \tau} \ldots
\end{aligned}
$$

The indirect effect of derivative usage on firm value, in this case, depends on the product of the relationship of derivative usage and a firm's risk (Model 3) and effect of firm's risk on value (Model 4). Hence, the indirect effect is.

Indirect effect $=a\left(b_{1}+b_{2}\right.$ DER $)$

Indirect effect $=a b_{1}+a b_{2}$ DER

Where, $a b_{1}$ is the intercept and $a b_{2}$ is the index of the moderated mediation, showing the relationship of derivative usage with the indirect effect of derivative usage on firm value through firm's risk. As derivative usage functions as a linear model of its own indirect effect on firm value.

\section{Empirical Findings and Discussions:}

Table 1 describes the summary statistics of Pakistani and Malaysian firms for the study period. Results show that Pakistani firms are using fewer FCD instruments for risk management in contrast to Malaysia. This may be because Malaysian firms are more operationally diversified which increases their ER exposure, result in more usage of FCD instruments. However, usage of IRDs is higher in Pakistan in contrast to Malaysia and the reason behind this is that Malaysia has developed debt and bond market which increases the firm's access to external financing at lower costs. Therefore, Malaysian firms are using fewer IRDs for risk management purpose. Findings depict that Pakistani and Malaysian firms have on average similar firm value, though Malaysian firms have a higher risk with respect to variability in operating cash flows.

Table No. 1: Summary Statistics of Pakistani Firms

\begin{tabular}{|l|l|l|l|l|}
\hline & Pakistan & Malaysia & \multicolumn{2}{l|}{$\begin{array}{l}\text { Standard } \\
\text { Deviation }\end{array}$} \\
\hline EXTFCD & Mean & $\begin{array}{l}\text { Standard } \\
\text { Deviation }\end{array}$ & Mean & 0.389 \\
\hline EXTINT & 0.018 & 0.049 & 0.045 & 0.163 \\
\hline FV & 0.207 & 0.277 & 0.068 & 4.719 \\
\hline FR & 1.464 & 2.556 & 1.470 & 0.6761 \\
\hline
\end{tabular}

Table 2 reports the univariate analysis results and conducts a non-parametric test in order to test whether the users and non-users are significantly different from each other with respect to firm value and risk. Results show that Pakistani derivative using firms have higher firm value and lower risk and users are significantly different from non-users in value and risk. Further analysis has been done by dividing the sample data based on firm's ER exposure and finds that firms having ER exposure, with respect to foreign sales, are using more FCD, however, they have significantly lower firm value in contrast to firm's having no ER exposure.

\begin{tabular}{|c|c|c|c|}
\hline $\begin{array}{l}\text { Firm Level } \\
\text { Characteristics }\end{array}$ & Using FCDs & $\begin{array}{l}\text { Firms not Using FCDs } \\
\text { (732) }\end{array}$ & $\begin{array}{l}\text { Tests } \\
\text { Differences }\end{array}$ \\
\hline FV & 1.676 & 1.361 & $0.001 * *$ \\
\hline FR & 0.013 & 0.022 & $0.000 * * *$ \\
\hline \multicolumn{4}{|c|}{ Summary Statistics for Pakistani Firms by ER Exposure } \\
\hline & $\begin{array}{l}\text { Firms having } \\
\text { Exposure } \\
(\mathbf{5 8 5})\end{array}$ & $\begin{array}{l}\text { Firms having no ER } \\
\text { Exposure } \\
\text { (495) }\end{array}$ & $\begin{array}{l}\text { Tests } \\
\text { Differences }\end{array}$ \\
\hline FCD & 0.406 & 0.228 & $0.000 * * *$ \\
\hline FV & 1.313 & 1.651 & $0.000 * * *$ \\
\hline
\end{tabular}

Table No. 2: Panel A: Summary Statistics for Pakistani Firms by FCD usage 
Panel B: Summary Statistics for Malaysian Firms by FCD usage

\begin{tabular}{|c|c|c|c|}
\hline $\begin{array}{l}\text { Firm-Level } \\
\text { Characteristics }\end{array}$ & $\begin{array}{l}\text { Firms using FCDs } \\
(\text { (503) }\end{array}$ & $\begin{array}{l}\text { Firms not using FCDs } \\
\text { (1221) }\end{array}$ & Tests for Differences \\
\hline FV & 1.384 & 1.472 & $0.000 * * *$ \\
\hline FR & 0.059 & 0.171 & $0.000 * * *$ \\
\hline
\end{tabular}

Summary Statistics for Malaysian Firms by ER Exposure

\begin{tabular}{|c|c|c|c|}
\hline & $\begin{array}{l}\text { Firms having ER } \\
\text { exposure (856) }\end{array}$ & $\begin{array}{l}\text { Firms having no ER } \\
\text { Exposure (889) }\end{array}$ & Tests for Differences \\
\hline FCD & 0.426 & 0.165 & $0.000 * * *$ \\
\hline $\mathrm{FV}$ & 1.340 & 1.594 & 0.281 \\
\hline FR & 0.111 & 0.162 & $0.000 * * *$ \\
\hline
\end{tabular}

Panel B demonstrates univariate analysis results of Malaysian firms and showed that firm value is lower for derivative users firms in contrast to non-users. This indicates that Malaysian firms are using natural or other risk management; therefore, usage of FCD instruments minimizes the value of Malaysian firms. An in-depth analysis shows that firms having ER exposure are significantly using more FCD instruments and have lower firm's risk.

Table No. 3 Panel A: Summary Statistics for Pakistani Firms by IRD Usage

\begin{tabular}{llllll}
$\begin{array}{l}\text { Firm-Level } \\
\text { Characteristics }\end{array}$ & $\begin{array}{l}\text { Firms } \\
(\mathbf{7 0 4})\end{array}$ & using & IRDs & $\begin{array}{l}\text { Firms } \\
(\mathbf{3 8 4})\end{array}$ & $\begin{array}{l}\text { Tests } \\
\text { Differences }\end{array}$ \\
\hline FV & 1.523 & 1.356 & $0.000^{* * *}$ \\
\hline FR & 0.018 & 0.022 & $0.001 * *$ \\
\hline
\end{tabular}

Summary Statistics for Pakistani Firms by IR exposure

\begin{tabular}{lllll}
\hline & $\begin{array}{l}\text { Firms having high IR } \\
\text { exposure (626) }\end{array}$ & $\begin{array}{l}\text { Firms having Low IR } \\
\text { exposure (462) }\end{array}$ & $\begin{array}{l}\text { Tests } \\
\text { Differences }\end{array}$ & for \\
\hline INT & 0.676 & 0.607 & $0.019^{* *}$ \\
\hline FV & 1.560 & 1.334 & $0.002^{* *}$ \\
\hline FR & 0.018 & 0.022 & $0.000^{* * *}$ \\
\hline
\end{tabular}

Panel B: Summary Statistics for Malaysian Firms by IRD usage

\begin{tabular}{llllll}
\hline $\begin{array}{l}\text { Firm-Level } \\
\text { Characteristics }\end{array}$ & $\begin{array}{l}\text { Firms } \\
(\mathbf{9 1 1})\end{array}$ & using & IRDs & $\begin{array}{l}\text { Firms not using } \\
\text { IRDs (835) }\end{array}$ & Tests for Differences \\
\hline FV & 1.212 & 1.751 & 0.125 \\
\hline FR & 0.116 & 0.160 & $0.001^{* *}$ \\
\hline
\end{tabular}

Summary Statistics for Malaysian Firms by IR Exposure

\begin{tabular}{llll}
\hline & $\begin{array}{l}\text { Firms having } \\
\text { IR Exposure (716) }\end{array}$ & $\begin{array}{l}\text { Firms having Low } \\
\text { IR exposure (1030) }\end{array}$ & Tests for Differences \\
\hline IRD & 0.623 & 0.451 & $0.000^{* * *}$ \\
\hline FV & 1.885 & 1.181 & $0.000^{* * *}$ \\
\hline FR & 0.104 & 0.161 & 0.393 \\
\hline
\end{tabular}

Table 3 demonstrates univariate analysis results of Pakistani firms with respect to IRD usage. Findings show that IRD users have significantly higher firm value and lower risk, measured by variability in operating cash flows. Detailed analysis depicts that firms having IR exposure are significantly using more IRD instruments and therefore have higher firm value and lower risk. Panel B depicts that derivative using firms have lower firm value and risk, though the value is not significantly different from users and non-users. The in-depthanalysis illustrates that firm's having IR exposure, with respect to interest coverage ratio, are using more IRDs and thus have higher firm value 
and lower risk. This reflects that firms having high IR exposure are using IRDs for risk management instruments.

Table 4 reports the empirical findings regarding the moderated mediation analysis of Pakistan and Malaysia. Results in column 1 show that Pakistani firms are using derivatives for value increasing purpose by minimizing firm's risk as shown by significant path ' $a$ ' and ' $b$ ', hence proving the mediating role of firm's risk on the relationship of derivative usage and firm value. However, no moderated effect of derivative usage is shown on the influence of derivative usage on firm value. This may be because of higher transaction costs of developing a derivative market which limits the risk management role of derivative instruments in presence of risky states. Findings depict the indirect effect of $0.69 \%$ of derivative usage on firm value, though the effect is not statistically significant as depicted by bootstrap confidence intervals. The study further classifies the data according to the types of derivative instruments and demonstrates moderated mediation results in column 2. Findings illustrate the significant mediating effect of firm's risk on the relationship of FCD usage and value of Pakistani firms. This implies that Pakistani firms can increase their firm value by using FCD instruments by minimizing risk. However, consistent with the results of column 1, derivative usage plays no moderating results on the indirect relationship of derivative usage with a value of Pakistani firms. Panel $\mathrm{C}$ shows that derivative usage indirectly affects firm value by $0.8 \%$ and the effect significantly ranges from $0.24 \%$ to $1.65 \%$, hence reflecting a conditional indirect effect of derivative usage on firm value through risk.

Study afterwards classifies the data on the basis of firm's ER exposure, measured with respect to FS, and depicts that Pakistani firms having no ER exposure can increase firm value by using FCD instruments through minimizing firm's risk as shown by significant path ' $a$ ' and ' $b$ '. This may be because firms are using FCDs for hedging their import payments as an appreciation of dollar enhances firm's ER exposure towards import payments. However, no conditional direct effect is shown as derivative usage has an insignificant moderating role on the relationship of risk and value, findings consistent with the earlier results. Panel $\mathrm{C}$ shows that derivative usage indirectly increases firm value by $1.06 \%$ and the effect is significant and may vary from $0.24 \%-2.57 \%$ as shown by bootstrap confidence intervals. However, results report no moderated mediating role of risk on the relationship of derivative usage and firm value. Column 4 documents moderated mediating results of firms having ER exposure and support earlier results that usage of FCD instruments indirectly enhances firm value by minimizing risk as proved by significant path ' $a$ ' and ' $b_{1}$ '.

Previous findings, derivative usage shows no conditional direct effect on firm value in presence of firm's risk. Panel $\mathrm{C}$ depicts that indirect effect of derivative usage on firm value is almost $0.67 \%$, however, theeffect is not statistically significant in nature. This may be because firm's receivables are dollar-denominated and constantly appreciating dollar against rupee enhances firm's receivables.

Results regarding IRD usage reports the significant mediating role of firm risk on the relationship of IRD usage with firm value as reported in column 5, implying that usage of IRDs in Pakistani firms give value premium incentives to them. However, consistent with the previous results, no significant moderating role is depicting on the relationship of derivative usage and firm value. Panel $\mathrm{C}$ proves the significant conditional indirect effect of almost $0.9 \%$, while the effect ranges from $0.26 \%$ to $2.38 \%$. Analysis has been done by further classification on the basis of firm's IR exposure, measured by interest coverage ratio, as firms having higher ability to pay finance payments are characterized under the head of high IR exposure firms and others as vice versa (Bartram et al., 2011). Findings show that firms having low-interest exposure are using derivatives for risk management purpose as derivative usage enhances firm value by reducing risk in column 6 . Consistent with the previous results, no conditional direct effect of the derivative is shown on the influence of derivative usage on firm value. Results depict significant partial mediation and report almost $0.21 \%$ effect of derivative usage on firm value. In case of firms having high-interest rate exposure, derivative usage fails to play a significant role as a risk management instrument in column 7 as results depict no conditional direct and indirect effect of IRD usage on firm value. This may be due to higher transaction costs of developing a derivative market which limits the usage of IRD instruments in firms having high IR exposure. 


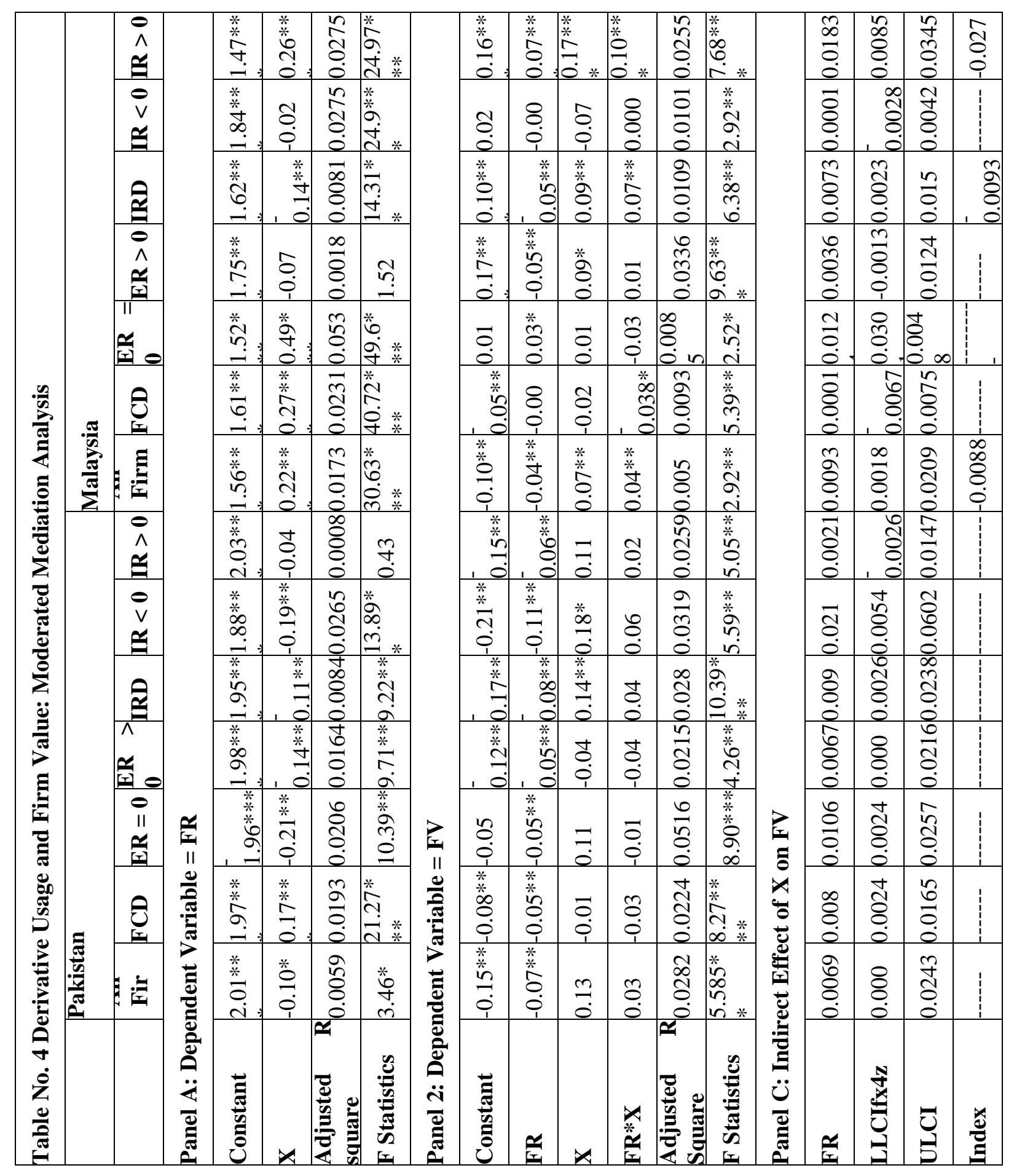


Column 8 shows results of Malaysian firms and depicts the existence of mediating role of firm's risk on the relationship of derivative usage and firm value, as illustrated by significant path 'a' and ' $b$ '. In addition to this, derivative usage plays a moderating role on the indirect effect of derivative usage on firm value. This indicates that derivative usage reports the significant indirect effect of almost, $0.93 \%$, on firm value. While theindex of moderated mediation value documents that indirect effect of derivative usage on firm value decreases with the derivative usage. This indicates that Malaysian firms can increase firm value, both directly and indirectly, by using derivative instruments regardless of firm's risk. Column 9demonstrates results of Malaysian firms using FCD instruments and showed that usage of derivatives reduces firm's risk, however, theinsignificant relationship of firm's risk with value suggests that despite risk reduction by derivative users, investors negatively value firms using FCDs as Malaysian firms are mostly involved in natural risk management activities. Findings further show that derivative usage negatively moderates the relationship of risk with value (significant path $\mathrm{b}_{2}$ ). This implies that Malaysian firms are more likely to involve in natural risk management strategies, thus firms having high risk are more likely to go for natural risk management strategies, rather than derivative usage. Therefore, usage of derivatives in presence of firm's risk negatively influences firm value. Moreover, Malaysian firms are mostly geographically diversified, hence investors perceived firms using FCDs for risk management purpose as a manipulative activity, thus value firms negatively.

Empirical analysis on the basis of firm's ER exposure shows that usage of FCDs in firms having no ER exposure reduces firm's risk in column 10. However, firm's risk reports the significant positive effect on value implying that usage of FCD instruments reduces firm's risk which in turn also minimizes value. This may because investors perceive high risky firms as growth-oriented and thus consider usage of FCD for risk management purpose as a speculative and manipulative activity, hence value negatively by investors. However, findings report no direct and conditional direct influence of derivative usage on firm value. Panel $\mathrm{C}$ depicts derivative usage indirectly minimizes firm value by $1.24 \%$, though the effect is not statistically significant as demonstrated by Bootstrap confidence interval values. For firms having ER exposure, usage of FCD documents insignificant negative effect on risk in column 11. This may be because Malaysian firms are mostly involved in natural and operational hedging techniques which limits the risk management role of FCD usage (Razali et al. 2008). Results find no significant moderated mediating effect of firm's risk on the relationship between FCD usage and firm value.

Findings regarding risk management role of IRD usage in Malaysian firms are demonstrated in column 12. Results show that firm's risk plays a significant mediating role in the relationship of derivative usage with firm value, as depicted by significant path ' $a$ ' and ' $b$ '. This indicates the usage of IRDs as a risk management instrument. Afterwards, study finds a positive moderating role of derivative usage on firm's risk and value, suggesting that usage of IRDs, in presence of firm's risk, enhances firm value. This indicates that comparatively developed derivative encourage firms to use IRDs as they can pay transaction costs. Panel $\mathrm{C}$ depicts thesignificant conditional indirect effect of $0.73 \%$ of derivative usage on firm value. Whereas index of moderated mediation report that indirect effect of derivative usage on firm value decreases with the firm's decision to use IRD instruments reflecting that usage of IRD in Malaysian firms increases firm value, irrespective of firm's risk. Analysis on the basis of firm's IR exposure demonstrates that firm value is irrelevant forderivative usage, reported in column 13. This may be due to the developed debt and bond market which facilitate investors in acquiring loans at preferable rates, hence limits the risk management role of IRD instruments. Column 14 reports the results of Malaysian firms having high IR exposure and shows significant path ' $a$ ' and ' $b$ ' implying that firm's risk mediates a relationship between IRD usage and firm value. Findings further prove the significant moderating role of derivative usage on the effect of IRD usage on firm value suggesting that in high IR exposure firms, usage of derivatives in risky states significantly enhances firm value. This implies that despite developed debt market, high IR exposure firms are using derivatives to avoid financial distress and thus have higher firm value. Panel $\mathrm{C}$ shows the significant indirect relationship of $1.83 \%$ of derivative usage on firm value, while the index of moderated mediation shows that indirect effect of derivative usage with firm value minimizes with the derivative usage, aligned with earlier results of column 12. This indicates that in high IR exposure firms, usage of IRD instruments enhances firm value, both conditionally direct and indirect, irrespective of the state of firm's risk. 
Summarizing the empirical findings, derivative usage identifies as a significant risk management instrument in both Pakistan and Malaysia. Though, the significance of derivatives, both FCD and IRD, minimizes in Pakistani firms in high-risk events due to higher transaction costs in relatively developing the derivative market. In contrast to Malaysia, the derivative market is comparatively developed which lowers the transaction costs, resulting in firm's decision to use derivatives even in high-risk circumstances. However, Malaysian firms are less likely to involve in FCD instruments as they are mostly naturally and operationally hedged. While, IRD instruments gives value incentives to high IR exposure firms, rather than low ones. As low IR exposure firms have easy access to external financing at lower rates due to the developed debt market.

\section{CONCLUSIONS}

Considering the growing significance of derivative usage all over the world and practitioners concern regarding the value relevance of derivative usage, vast number of studies have been done in determining the effect of financial derivatives on firm value. However, empirical evidence on the path through which financial derivatives enhance firm value is still missing. Present study primarily contributes to existing literature by examining 'how' and 'when' derivative usage enhances firm value by using Bootstrap techniques by Hayes (2015). In addition to this, study comparative analyses the role of derivative used as a risk management in Pakistani and Malaysian non-financial firms for the year of 2004-2010. Empirical findings depict that Malaysian firms have both conditional direct and indirect effect of derivative usage on firm value as firm's risk moderated mediates the relationship of derivative usage and firm value. While in Pakistan, derivative usage has an only conditional indirect effect on firm value. The reason may be higher transaction costs of developing a derivative market which hinders the risk management role of derivatives in high-risk states.

The study, therefore, helpspolicy makers in developing the need for the well-defined derivative market, so that firms can increase their value by using derivatives regardless of risk. Findings facilitate managers in identifying how and when the decision to use derivatives enhances firm value in both Pakistan and Malaysia. Future research could be possible by using alternative measures of firm's risk and value. In addition to this, a detailed comparative analysis can be done by using sample data of counties where derivative markets are developed like US, UK with the one where derivative market is developed and underdeveloped.

\section{REFERENCES}

Afza, T., \& Alam, A. (2016). Foreign currency derivatives and firm value. European Online Journal of Natural and Social Sciences, 5(1): 1-14.

Akpınar, O., \& Fettahoğlu, A. (2016). Does the use of derivatives affect firm value? Evidence from Turkey. Journal of transnational management, 21(2): 53-61.

Allayannis, G., Brown, G. W., \& Klapper, L. F. (2001). Exchange rate risk management: Evidence from East Asia. World Bank policy research working paper (2606).

Allayannis, G., Ugur, L., \& Miller, D. (2012). The use of foreign currency derivatives, corporate governance, and firm value around the world. Journal of International Economics, 87(1): 6579.

Ameer, R. (2009). Value-relevance of foreign exchange and interest-rate derivatives disclosure the case of Malaysian firms. Journal of Risk Finance, 10(1): 78-90.

Ayturk, Y., Gurbuz, A. O., \& Yanik, S. (2016). Corporate derivatives use and firm value: Evidence from Turkey. Borsa Istanbul Review, 16(2): 108-120.

Bachiller, P., Boubaker, S., \& Mefteh-Wali, S. (2021). Financial derivatives and firm value: What have we learned? Finance Research Letters, 39: 101573.

Bae, S. C., Kim, H. S., \& Kwon, T. H. (2018). Currency derivatives for hedging: New evidence on determinants, firm risk, and performance. Journal of futures markets, 38(4): 446-467.

Baron, R. M., \& Kenny, D. A. (1986). The moderator-mediator variable distinction in social psychological research: Conceptual, strategic, and statistical considerations. Journal of personality and social psychology, 51(6): 1173-1182.

Bartram, S. M., Brown, G. W., \& Conrad, J. (2011). The effects of derivatives on firm risk and value. Journal of Financial and Quantitative Analysis, 46(4): 967-999. 
Bashir, H., Khurram S., \& Jghef, O. K. (2013). Impact of Derivative Usage on Firm Value: Evidence from Non-Financial Firms of Pakistan. Journal of Management Research, 5(4): 108-127.

Carter, D. A., Rogers, D. A., \& Simkins, B.J. (2006). Hedging and Value in the U.S Airline Industry. Journal of Applied Corporate Finance, 18(4): 21-33.

Chang, F.-Yi., Hsin,C-W., \& Shiah -Hou, S-R. (2010). The Impact of Currency Derivative Usage and Earnings Management on Firm Value.

Chen, J., \& King, T-H. D. (2014). Corporate hedging and the cost of debt. Journal of Corporate Finance, 29: 221-245.

Choi, J. J., Mao, C. X., \& Upadhyay, A. D. (2013). Corporate Risk Management under Informational Asymmetry. Journal of Business Finance and Accounting, 40(1-2): 239-271.

Clark, E., \& Mefteh, S. (2010). Foreign Currency Derivatives Use, Firm Value and the Effect of the Exposure Profile: Evidence from France. International Journal of Business, 15(2): 183.

DeMarzo, P. M., \& Duffie, D. (1995). Corporate incentives for hedge and hedge accounting. Review of Financial Studies, 8(3): 743-71.

Faseruk, A., \& Mishra, D. R. (2008). An examination of US dollar risk management by Canadian non-financial firms. Management of Research news, 31(8): 570-582.

Fauver, L., \& Naranjo, A. (2010). Derivative usage and firm value: The influence of agency costs and monitoring problems. Journal of Corporate Finance, 16(5): 719-735.

Firmansyah, A., \& Purnama, E. B. D. (2020). Do Derivatives Instruments Ownership Decrease Firm Value in Indonesia? Riset Akuntansi dan Keuangan Indonesia, 5(1): 1-9.

Frensidy, B., \& Mardhaniaty, T. I. (2019). The Effect of Hedging with Financial Derivatives on Firm Value at Indonesia Stock Exchange. Economics and Finance in Indonesia, 65(1): 20-32.

Froot, K. A., Scharfstein, D. S., \& Stein, J. C. (1993). Risk Management: Coordinating Corporate Investment and Financing Policies. Journal of Finance, 48(5): 1629-1658.

Graham, J. R., \& Rogers, D. A. (2002). Do firms hedge in response to tax incentives?. Journal of Finance, 57: 815-839.

Hayes, A. F. (2015). An index and test of linear moderated mediation. Multivariate Behavioral Research, 50(1): 1-22.

Hayes. A. F. (2012). Process: A versatile computational tool for observed variable mediation, moderation and conditional process modelling.

James, L. R., \& Brett, J. M. (1984). Mediators, Moderators and tests for mediation. Journal of Applied Psychology, 69(2): 307-321.

Judd, C. M., \& Kenny, D. A. (1981). Process analysis estimating mediation in treatment evaluations. Evaluation Review, 5(5): 602-619.

Junior, J. L. R., \& Laham, J. (2008). The Impact of Hedging on Firm Value: Evidence from Brazil. Journal of International Finance and Economics, 8(1):1-16

Kadir, A. D. (2003). Minister of Culture and Tourism Malaysia stated during his visit to Pakistan. Dawn (Karachi), 18 July.

Kapitsinas, S. (2008). Derivatives usage in risk management by non-financial firms: Evidence from Greece. Submitted to MPRA paper No. 10945.

Khediri, B. K. B. (2010). Does investors really value derivatives use? Empirical evidence from France. Journal of Risk Finance, 11(1): 62-74.

Khediri, K. B., \& Folous, D. (2010). Does hedging increase firm value? Evidence from French firms. Applied Economics Letter, 17(10): 995-998.

Krause, T.A., \& Tse, Y. (2016), "Risk management and firm value: recent theory and evidence", International Journal of Accounting \& Information Management, 24(10): 5681. https://doi.org/10.1108/IJAIM-05-2015-0027

Lau, C. K. (2016). How corporate derivatives use impact firm performance?. Pacific-Basin Finance Journal, 40: 102-114.

Leland, H. E. (1998). Agency Costs, Risk Management and capital Structure. Journal of Finance 53(4): 1213-43.

Lenee, T. L., \& Oki, J. (2017). Financial derivatives and firm performance: empirical evidence from financial and non-financial firms. Journal of Economics, Management and Trade, 16(4); 136. 
León, C., Gomez-Gonzalez, J. E., \& Rodriguez, K. (2009). Does the Use of Foreign Currency Derivatives Affect Colombian Firms' Market Value?. Borradores de Economía, (562).

Lookman, A. (2004). Does hedging increase firm value? Evidence from oil and gas producing firms, In EFA 2004 Maastricht Meetings. Paper (No. 5174).

Luo, Hang Robin, and Rui Wang. (2018). Foreign currency risk hedging and firm value in China. Journal of Multinational Financial Management, 47: 129-143.

Mackay, P., \& Moeller, S. B. (2007). The value of corporate risk management. The Journal of Finance, 62(3): 1379-1419.

Mayers, D., \& Smith, C.W. (1982). On the Corporate Demand for Insurance. Journal of Business 55(2): 281-96.

Merton, R. C. (1989). On the application of the Continuous -Time theory of Finance to Financial Intermediation and Insurance, Geneva Papers on Risk and Insurance, 14(52): 225-261.

Monda, B., Giorgino, M. \& Modolin, I. (2013). Rationals for Corporate Risk Management- A Critical Literature Review. Available at SSRN 2203546.

Myers, S. C., \& Majluf, N. (1984). Corporate financing and investment decisions when firm have information that investors do not have. Journal of Financial Economics, 13(2): 187-221.

Naito, J., \& Laux, J. A. (2011). Derivatives Usage: Value-Adding Or Destroying?, Journal of Business and Economics Research, 9(11):41-50

Nguyen, H., \& Faff, R. (2010). Does the type of derivative instruments used by companies impact firm value? Applied Economics Letter, 17(7): 681-683.

Paligorova, T., \& Staskow, R. (2014). The Use of Financial Derivatives by Canadian Firms. Bank of Canada Review 2014 (Autumn): 47-54.

Panaretou, A. (2014). Corporate Risk Management and Firm Value: evidence from the UK market. The European Journal of Finance, 20(12): 1161-1186.

Phan, D., Nguyen, H., \& Faff, R. (2014). Uncovering the asymmetric linkage between financial derivatives and firm value - The case of oil and gas exploration and production companies. Energy Economics, 45(September): 340-352.

Smith, C. W., \& Stulz, R. M. (1985). The determinants of firm are hedging policies. Journal of Financial and Quantitative Analysis, 20(4): 391-405.

Tufano, P. (1996.) Who manages risk? An empirical examination of risk management practices in the gold mining industry. Journal of Finance, 51: 1097-1137.

Vivel Búa, M., Otero González, L., Fernández López, S., \& Durán Santomil, P. (2015). Is value creation consistent with currency hedging?. The European Journal of Finance, 21(10-11): 912-945. 